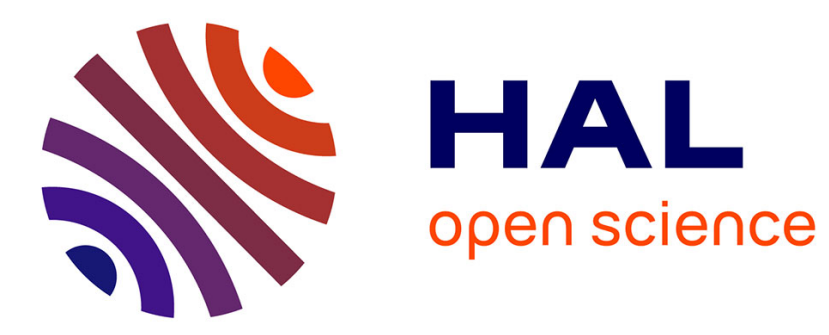

\title{
Preparing particle reinforced Al-MMCs by mechanical alloying
}

\author{
E. Hochreiter, C. Kowanda, B. Ortner
}

\section{To cite this version:}

E. Hochreiter, C. Kowanda, B. Ortner. Preparing particle reinforced Al-MMCs by mechanical alloying. Journal de Physique IV Proceedings, 1993, 03 (C7), pp.C7-1829-C7-1832. 10.1051/jp4:19937291 . jpa-00251934

\section{HAL Id: jpa-00251934 https://hal.science/jpa-00251934}

Submitted on 1 Jan 1993

HAL is a multi-disciplinary open access archive for the deposit and dissemination of scientific research documents, whether they are published or not. The documents may come from teaching and research institutions in France or abroad, or from public or private research centers.
L'archive ouverte pluridisciplinaire HAL, est destinée au dépôt et à la diffusion de documents scientifiques de niveau recherche, publiés ou non, émanant des établissements d'enseignement et de recherche français ou étrangers, des laboratoires publics ou privés. 


\title{
Preparing particle reinforced Al-MMCs by mechanical alloying
}

\author{
E. HOCHREITER, C. KOWANDA and B. ORTNER ${ }^{*}$
}

Institut für Metallkunde und Werkstoffprüfung, Montanuniversität, 8700 Leoben, Austria

* Institut für Metallphysik Montanuniversität, 8700 Leoben, Austria

\begin{abstract}
The properties of particle reinforced metal matrix composites (MMCs) are largely influenced by the homogeneity of the particle distribution. The possibility of the fabrication of $\mathrm{MMC}$ powders with a homogeneous particle distribution, a high bulk density and low gas contents by the process of mechanical alloying have been investigated. The milling atmosphere and the type of process control agent have been varied in order to optimize the gas contents and furthermore to take advantage of additional strengthening by oxide or carbide formation. Measurements of the microhardness, the bulk density, the homogeneity of the particle distribution and the gas contents have been done. The progress in reaction milling of graphite has been studied by XRD measurements.
\end{abstract}

\section{Introduction}

The process of mechanical alloying (MA) can be used to produce alloys that are difficult or impossible to be produced by conventional melting and casting techniques. MA is a process of repeated fracturing and cold welding of a powder mixture in an attritor (high energy ball mill) This process leads to alloy formation, a refined microstructure and the redistribution of insoluble particles. Therefore MA has received increased attention due to its potential for the fabrication of dispersion strengthened alloys, for the production of alloys with very even element distribution and fine subgrain structure and of alloys with amorphous structure $[1,2]$. MA of ductile powders like aluminium needs the addition of an as-called process-control-agent (PCA) to prevent immoderate cold-welding.

Particle reinforeced Al-MMCs are of special interest because of their improved properties as stiffness, strength, wear resistance, creep behaviour and low coefficiant of thermal expansion compared with the monolithic alloys [3-9]. The extent of property improvement of MMCs at a given particle chemistry, size and volume fraction is related to the homogeneity of the particle distribution. In special fatigue crack initiation is largely dependent on clustering of particles [10]. MA should be a process step

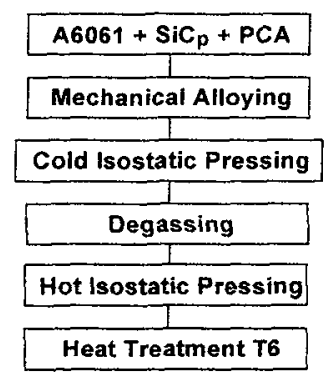

fig. 1: PM production route of MMCs

within the HIP PM-production route (fig. 1) which makes it possible to produce a composite powder with a homogeneous particle distribution. The quality of the particle distribution is important as it is nearly not influenced by the following process steps. Due to the requirements of the consolidation process and the material properties the aim of the MA process is to produce a composite powder with a homogeneous particle distribution, a low gas content and a powder geometry suited for CIP and HIP processes.

\section{Experimental Procedure}

Prealloyed aluminium alloy powder $\mathrm{A} 6061$ ( $\mathrm{AlMgSiCu}$ ) from Pechiney was mechanically alloyed with 15 vol.\% of $\mathrm{SiC}$ particles $\left(\mathrm{SiC}_{\mathrm{p}}\right)$ and the needed additives. The average particle sizes are $40 \mu \mathrm{m}$ for $\mathrm{A} 6061$ and $4.5 \mu \mathrm{m}$ for $\mathrm{SiC}_{\mathrm{p}}$. MA experiments were performed for 2 hours at a mass ratio of milling balls to powder of 20 . The PCA and the milling atmosphere have been varied as listed in table 1. The MA powders have been characterized by measurements of microhardness, bulk density and homogeneity of the $\mathrm{SiC}_{\mathrm{p}}$-distribution. The microhardness has been measured using a Vickers Reichert-Jung hardness tester under a load of $0.1 \mathrm{~N}$. 
Tab. 1: Parameters for mechanical alloying experiments

\begin{tabular}{c|cc}
\hline material & process control agent & milling atmosphere \\
\hline $\mathrm{A}$ & $0.5 \mathrm{wt} \%$ stearic acid & argon \\
$\mathrm{B}$ & $0.5 \mathrm{wt} \%$ stearic acid & air \\
$\mathrm{C}$ & $2 \mathrm{wt.} \%$ graphite & argon \\
$\mathrm{D}$ & $2 \mathrm{wt.} \%$ graphite & air \\
\hline
\end{tabular}

Furthermore the $\mathrm{H}_{2} \mathrm{O}$-gas contents have been determined using an Aquanal $\mathrm{H}_{2} \mathrm{O}$-gas measurement system. The temperature profile has been selected similar to degassing and HIP conditions to $200^{\circ} \mathrm{C} / 2 \mathrm{~h} ; 535^{\circ} \mathrm{C} / 3 \mathrm{~h}$; heating rate $10^{\circ} \mathrm{C} / \mathrm{min}$. X-ray diffraction measurements (XRD) have been done in order to investigate the MA process. XRD spectra were recorded with a Siemens F goniometer using $\mathrm{Cr} \mathrm{K} \alpha$ radiation.

\section{Results and Discussion}

MA of aluminium powders requires a PCA which is of great importance because of several reasons:

1) As shown by Benjamin [11] the resulting particle size is determined by the mutual mechanism of dominated welding of small powder grains and dominated grinding of larger powder grains, due to the fact that powder particle strength is somehow related to the in versal of the square root of the powder grain size. The addition of a PCA influences the stabilized particle size of MA powder. An increase of the PCA contens will strongly reduce the particle size because of empeding the welding of powder particles to each other.

2) The PCA undergoes some reaction milling, this means if carbon or oxide is introduced inside the powder by MA carbides $\left(\mathrm{Al}_{4} \mathrm{C}_{3}\right)$ and oxides $\left(\mathrm{Al}_{2} \mathrm{O}_{3}\right)$ will be formed by a reaction with aluminium.

3) As the PCA influences the amount of cold welding it prevents excessive welding of the ductile powder to the attritor and the milling balls.

The milling atmosphere is of a great importance, too. MA in an inert gas atmosphere prevents the formation of aluminium oxide surface layers on the "clean" surfaces of fractured particles. As these surfaces are of a high reactivity, MA in inert gas atmosphere facilitates cold welding and results in fast particle coarsening.

MA in air hinders the cold welding processes, but at last the formation of $\mathrm{Al}_{2} \mathrm{O}_{3}$ oxides should be raised.

Optical micrographs of the unetched powder cross-section of MA-powders A-D (see table 1, fig. 2a-d) show a quite different appearance. In general the use of graphite as PCA results in a significant smoother powder surface than the use of stearic acid. The same tendence can be observed for powder MA in argon atmosphere compared with powders MA in air. Although it has to be considered, that influence of the milling atmosphere on the cold welding process is correlated to the PCA-contents and somehow to the input of the milling energy, powder MA in air does not exhibit a satisfacturing powder geometry at given milling conditions.

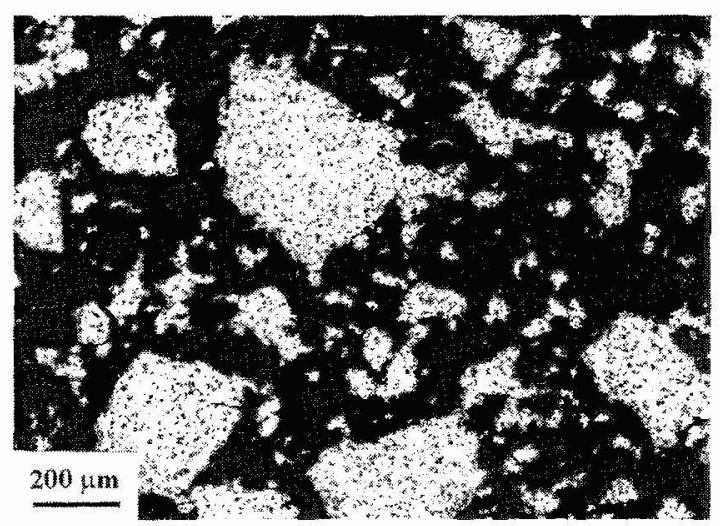

fig. 2a: $\mathrm{MA} \mathrm{SiC} / \mathrm{A} 6061$; stearic acid, argon

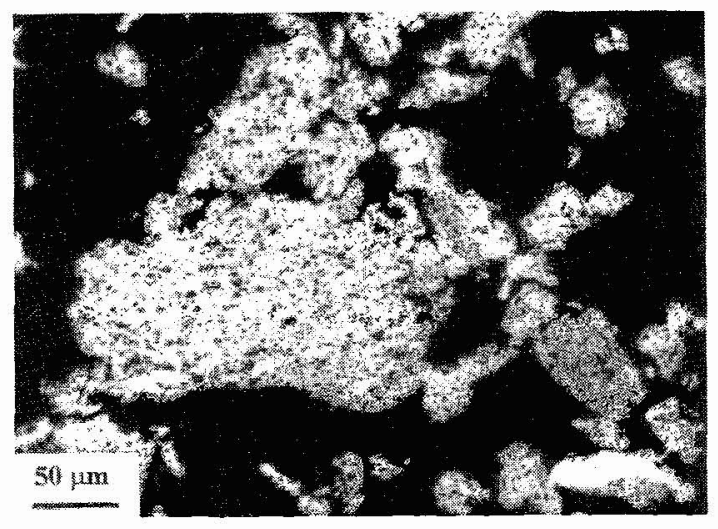

fig. 2b: $\mathrm{MA} \mathrm{SiC} / \mathrm{A6061}$; stearic acid, air

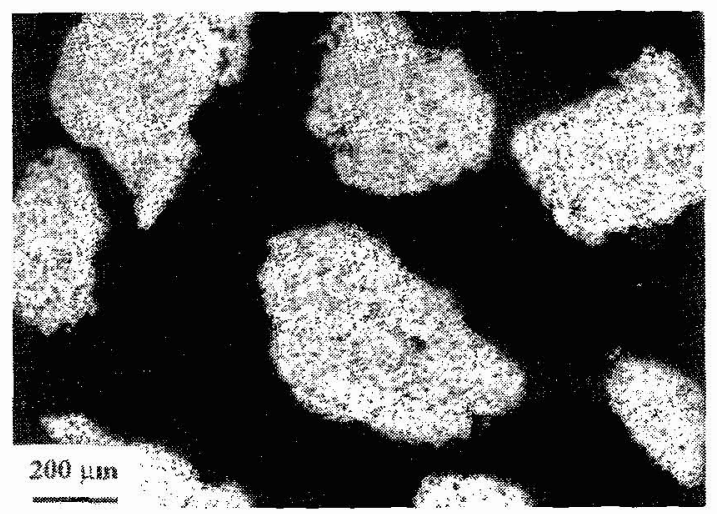

fig. $2 \mathrm{c}: \mathrm{MA} \mathrm{SiC} / \mathrm{A6061}$; graphite, argon 


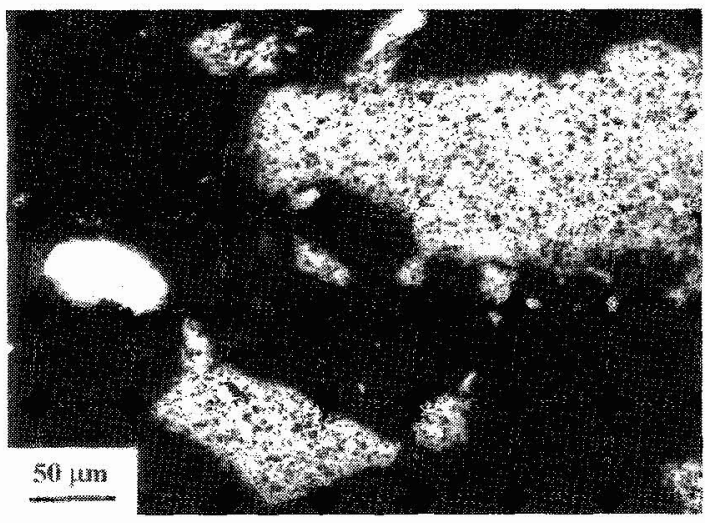

fig. 2d: $M A S_{\text {SiC }} / A 6061$; graphite, air

Fig. 3 shows the increase of the bulk density from about $50 \%$ to $55 \%$ for powder MA in air and argon atmosphere, due to the correlation of the bulk density to the powder geometry and the surface roughness.

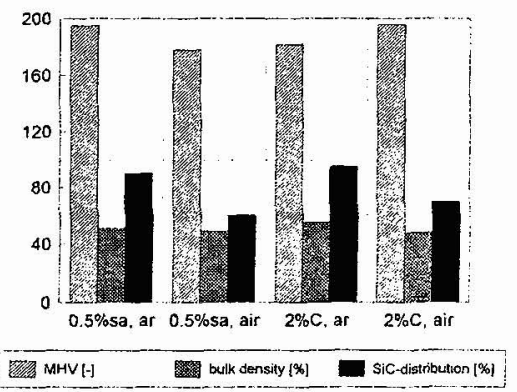

fig. 3: properties of $\mathrm{MA} \mathrm{SiC} / \mathrm{A6061}(\mathrm{sa}=$ stearic acid)

Measurements of the microhardness show comparable values of about $190 \mathrm{HV}$. Of a great importance is the homogeneity of the $\mathrm{SiC}_{\mathrm{p}}$-distribution which can vary per definition from 0 to $100 \%$. Powder MA in argon atmosphere with graphite as $\mathrm{PCA}$ shows a $\mathrm{SiC}_{\mathrm{p}}$ - distribution which is rather perfect. Powders $\mathrm{MA}$ in air in general exhibit a decrease in the homogeneity of the $\mathrm{SiC}_{\mathrm{p}}$-distribution due to some small powder particles which are not MA. This is maybe caused by the immediate coverage of the fractured particles with an $\mathrm{Al}_{2} \mathrm{O}_{3}$-layer which hinders cold welding (see fig. 2 d). Due to this reason, MA in air leads to a decrease in the efficiency of the MA process. This means, it would take longer milling times or a higher energy input to reach the steady state. This is quite important as the $\mathrm{SiC}_{\mathrm{p}}$-distribution can hardly be influenced by the following consolidation steps like cold isostatic pressing, degassing and HIP. Therefore MA will determine the properties of the consolidated material.

Measurements of the $\mathrm{H}_{2} \mathrm{O}$-gas contents of a given temperature profile exhibit the lowest gas contents for powder with the PCA graphite added and which is MA in argon atmosphere (fig. 4). The higer gas contents of powder MA in air is due to the introduction of air humidity into the

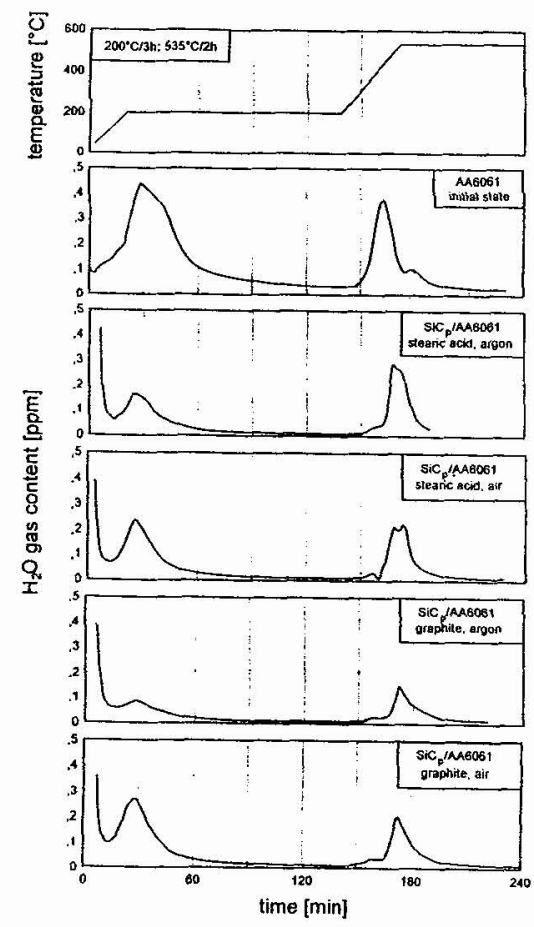

fig. 4: Measurements of the $\mathrm{H}_{2} \mathrm{O}$-gas contents of $\mathrm{MA}$ $\mathrm{SiC}_{\mathrm{p}} / \mathrm{A6061}$

powders. The organic compound stearic acid $\left(\mathrm{CH}_{3}\left(\mathrm{CH}_{2}\right)_{16} \mathrm{CO}_{2} \mathrm{H}\right)$ will at least introduce $\mathrm{H}_{2}$ gas during the MA process which causes an increase in the gas content, too. Our measurements are in good agreement with results reported from Jangg [12] who found, that at temperatures from 100 to 350 degrees almost all adsorbed water is evaporated and all hydroxides have been dissociated.

The formation of hydrogen which remains in the granulates is unwelcome, as materials consolidated from such powders exhibit poor quality [12]. Since the $\mathrm{H}_{2} \mathrm{O}$ contents is somehow correlated to the $\mathrm{H}_{2}$ contents, material $\mathrm{C}$ (table 1) should exhibit the lowest $\mathrm{H}_{2}$ contents due to milling in inert atmosphere and to the addition of graphite.

XRD measurements of powders MA in argon atmosphere with the PCA graphite added have been done. Measurements have been performed on powders MA for 1, 2 and 4 hours and on powder MA for 2 hours followed by a 530 ${ }^{\circ} \mathrm{C} / 2 \mathrm{~h}$ heat treatment. It was the aim to investigate the expected mechanical alloying process for graphite which should be put in solid solution followed by the formation of $\mathrm{Al}_{4} \mathrm{C}_{3}$. These stable carbides exhibit high hardness and shear strength and they are practically insoluble in A1 even close to the melting point. Therefore the formation of $\mathrm{Al}_{4} \mathrm{C}_{3}$ is not unwelcome, as it will cause an increase in material strength. It is visible (fig. 5) that the most intensive $C(002)$ peak disappears at milling times of 1 hours. The formation of $\mathrm{Al}_{4} \mathrm{C}_{3}$ could not be prooved, even after 


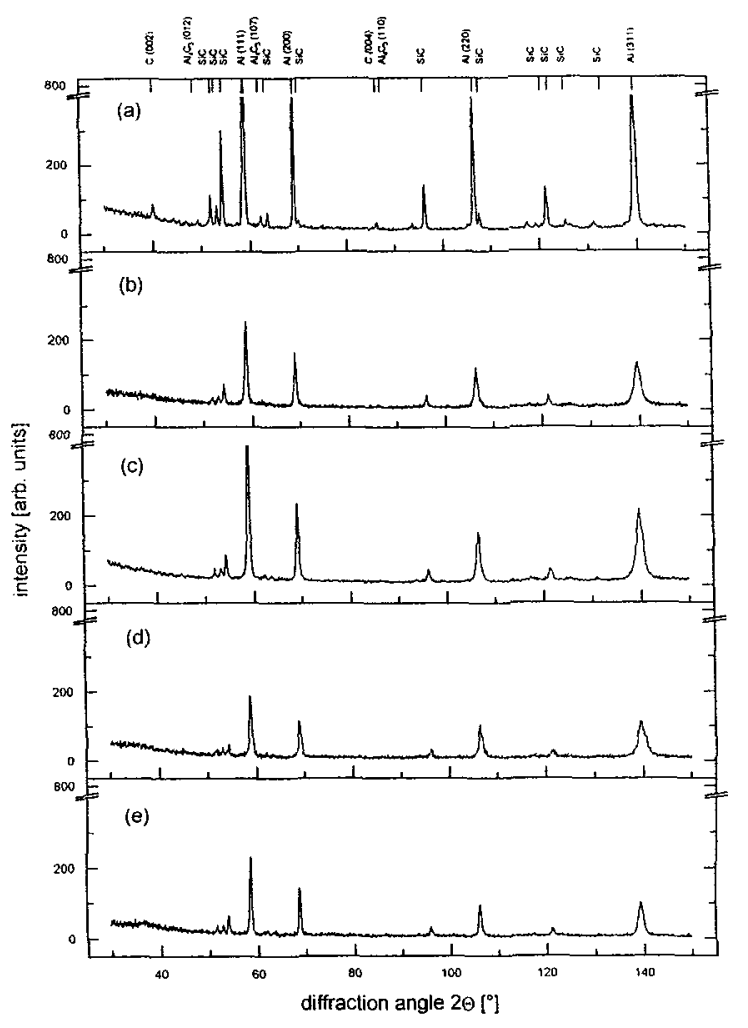

fig. 5: XRD measurements of $\mathrm{SiC}_{\mathrm{p}} / \mathrm{A} 6061+2 \%$ graphite: a) powder mixture b) $M A-1 h$, argon c) $M A-2 h$, argon d) MA-4h, argon e) MA-2h, argon $+530^{\circ} \mathrm{C} / 2 \mathrm{~h}$

a heat treatment of 2 hours at $530^{\circ} \mathrm{C}$. This could be reasoned by the low amount of $\mathrm{Al}_{4} \mathrm{C}_{3}$ which is hard to detect by XRD as some peaks overlap.

Jangg reported [12] that $\mathrm{Al}_{4} \mathrm{C}_{3}$ formation in $\mathrm{MA} \mathrm{Al}+$ $2 \mathrm{wt} \%$ graphite needs some additional heat treatment at similar milling conditions. Dependend on the type of graphite used, the $\mathrm{Al}_{4} \mathrm{C}_{3}$ formation will be completed after a heat treatment of about 3 hours. Therefore it can be expected that carbide formation will be completed within the heat treatment necessary for the degassing and the HIP process $\left(200^{\circ} \mathrm{C} / 2 \mathrm{~h}\right.$ and $\left.535^{\circ} \mathrm{C} / 2 \mathrm{~h}\right)$.

\section{Conclusion}

Apart from the fact, that the process of MA is determined by quite a lot of parameters it has been found that the production of a powder $\mathrm{A} 606 \mathrm{I}+15$ vol. $\% \mathrm{SiC}_{\mathrm{p}}$ with an homogeneous particle distribution, a smooth powder surface, a near-spherical powder geometry and a low gas content is possible by $\mathrm{MA}$ in argon atmosphere and adding 2 wt.\% graphite as PCA.

In general $\mathrm{MA}$ in air causes an increasing oxide content and insufficiant cold welding. MA in inert atmosphere and the replacement of the conventional PCA stearic acid by graphite causes a uniform powder size, a smooth powder surface and lower gas contents. Furthermore carbide formation should take place after a heat treatment which is necessary for the degassing and HIP processes.

\section{References}

[1] Le Brun, P., Froyen, L., Munar, B. and Delaey, L., Scandinavian Journal of Metallurgy 19 (1990), 19

[2] Kaneko, J.,Sugamata, M. and Horiuchi, R. in Austria Metall AG. (ed.), Proc. 8. Internationale Leichtmetalltagung, Aluminium-Verlag, Düsseldorf, Germany (1987) 776

[3] Shang, J.K, Yu, W. and Ritchie, R.O., Mater. Sci. Eng. $A, 102$ (1988) 181

[4] DiVecha, A.P., Fishman, S.G. and Karmarkar, S.D., J. Met., 33 (1981) 12

[5] Arsenault, R.J., Mater. Sci. Eng., 64 (1984) 171

[6] Crowe, C.R., Gray, R.A. and Hasson, D.F. in Harrigan, W., Strife, J. and Dhingra, A.K. (eds.), Proc. 5th Int. Conf. on Composite Materials, Metallurgical Society of AIME, Warrendale, PA, (1985) 843

[7] Nair, S.V., Tien, J.K. and Bates, R.C., Int. Metall. Rev., 30 (1985) 275

[8] Srivatsan, T.S., Auradkar, R., Lavernia, E.J. and Prakash, A., Mater. Trans., JIM, 32 (1991) 473

[9] Kumai, S., King, J.E. and Knott, J.F., Fatigue Fract. Engng. Mater. Siruct., 13 (1990) 511

[10] Hochreiter, E., Panzenböck, M. and Jeglitsch, F., Fatigue Properties of Particle Reinforced Metal Matrix Composites, Int. J. Fat., will be published fall 1993

[11] Benjamin, J.S., Materials Science Forum Vols. 88-90 (1992) 1

[12] Jangg, G., Radex-Rundschau, 2/3 (1986) 169 